\title{
Triangular negotiations of island sovereignty: Indigenous and customary authorities - metropolitan states - local metropolitan authorities
}

\author{
Cadey Korson \\ Massey University, Aotearoa New Zealand \\ C.Korson@massey.ac.nz (corresponding author)
}

\section{Sybille Poaouteta}

Independent researcher, New Caledonia

sybillepoaouteta@yahoo.fr

\section{Gerard Prinsen \\ Massey University, Aotearoa New Zealand \\ G.Prinsen@massey.ac.nz}

\begin{abstract}
The benefits of subnational island jurisdiction (SNIJ) status are well detailed, but less attention has been given to the diffusion of economic, social and political benefits associated with these islands' Islandian sovereignty among diverse island populations. The 2007 UN Declaration on the Rights of Indigenous Peoples indicated the international community's formal recognition of Indigenous peoples' rights to political self-determination and govern their own affairs through their own decision-making institutions, and requires states to consult with these organisations to obtain free, prior and informed consent. Yet, few SNIJs with Indigenous peoples have established or restored Indigenous bodies of authority distinct from local governments. In the context of Islandian sovereignty and the unique power relationships organised between metropoles and islands, we consider how Indigenous authorities negotiate independence and dependence, statehood and non-sovereignty, autonomy and control. This article offers a foundational typology for thinking about these multilateral relations between metropoles, SNIJs, and customary or Indigenous authorities.
\end{abstract}

Keywords: governance, Indigenous peoples, Islandian sovereignty, islands, United Nations Declaration on Indigenous Rights

https://doi.org/10.24043/isj.112 • Received June 2019, accepted January 2020

(C) 2020-Institute of Island Studies, University of Prince Edward Island, Canada.

\section{Introduction}

The economic benefits of metropole-island associations have been well documented and a growing body of research examines how the 40 to 120 or so (depending on the definition 
used) unlikely-to-seek-full-sovereignty islands relate to, and negotiate with, metropolitan authorities (Rezvani, 2014; Stuart, 2008). Certainly, the reciprocal nature of these relationships is perpetuated by economic and strategic benefits to both subnational island jurisdictions (SNIJ) and their respective metropolitan powers. Baldacchino (2017, p. 100) recently concluded SNIJs have successfully achieved "Autonomy Plus." In the same vein, Prinsen and Blaise (2017) argue that SNIJ leaders gaining exceptional domestic and international autonomy while retaining the benefits of association actually represents a particular kind of Islandian sovereignty. Indeed, at the supranational level, SNIJs belonging to the EU's Overseas Countries and Territories enjoy the benefits of EU membership but retain varying degrees of domestic autonomy in a broad range of policy areas, from trade to residency, banking, same sex marriage, environmental legislation and voter eligibility.

However, less attention is given to the diffusion of benefits associated with Islandian sovereignty among diverse island populations. How do Indigenous or marginalised peoples, through Indigenous and customary authorities, negotiate greater sovereignty or particular rights vis-à-vis colonial settler populations, recent migrants or state institutions? The 2007 UN Declaration on the Rights of Indigenous Peoples (UNDRIP) indicated the international community's formal recognition of Indigenous peoples' rights to political self-determination and govern their affairs through their own decision-making institutions, and requires states to consult with these organizations to obtain free, prior and informed consent. Against the backdrop of UNDRIP and drawing on literature and policy documents from France, Chile and Australia, we present an inventory of SNIJs as a basis for further research into the ways in which island customary or Indigenous authorities negotiate independence and dependence, statehood and non-sovereignty, autonomy and control, with local government authorities and metropolitan states.

\section{Subnational island relations and Indigenous rights in international law}

In 1945, Article 73 of the UN Charter established a framework of trusteeship whereby colonising countries would assist their colonies in developing self-government and eventually independence. The 1960 Declaration on the Granting of Independence to Colonial Countries and Peoples, reaffirmed all peoples' right to self-determination. While full independence was clearly the aim, the declaration provided three options for self-determination: 1) full sovereignty, 2) free association with an independent state, or 3) integration with an independent state (Declaration, 1960). Freely associated states could draft their own constitution and democratically change their status at any time. Integration meant becoming equal partners with the state, so long as the integrating population first establishes a strong government and the opportunity to provide free and informed consent to integrate (Declaration, 1960). These documents addressed self-determination in the colonial context, but said nothing about the rights or definition of Indigenous peoples.

An initial definition of Indigenous peoples is provided in Article 1 of the Indigenous and Tribal Populations Convention from 1957, or ILO 107. Indigenous tribal or semi-tribal peoples are defined by: "their descent from the populations which inhabited the country, or a geographical region to which the country belongs, at the time of conquest or colonisation and which, irrespective of their legal status, live more in conformity with the social, economic and cultural institutions of that time than with the institutions of the nation to which they 
belong" (ILO, 1957). However, the goals of ILO 107— "the protection of the populations concerned, their progressive integration into their respective national communities, and the improvement of their living and working conditions" - were assimilationist and the definition of Indigenous peoples was expanded by Special Rapporteur, José R. Martinez Cobo, in his 1982 Study of the Problem of Discrimination against Indigenous Peoples. In the study, Cobo highlights the importance of understanding how countries classify Indigenous peoples and the right of Indigenous peoples to define themselves. Cobo (1983, p. 50) offers a series of preliminary criteria for defining Indigenous peoples from an international perspective, including pre-colonial connection, they present a distinctive minority, and a desire to preserve their identity through "their own cultural patterns, social institutions and legal systems." Using elements of these definitions, the legally binding convention on the rights of Indigenous peoples, the 1989 International Labour Organization's Indigenous and Tribal Peoples Convention No. 169 defines Indigenous peoples as peoples whose (ILO, 1989):

social, cultural, and economic conditions distinguish them from other sections of the national community, and whose status is regulated wholly or partially by their own customs or traditions or by special laws or regulations; [...] descent from the populations which inhabited the country, or a geographical region to which the country belongs, at the time of conquest or colonisation or the establishment of present state boundaries and who, irrespective of their legal status, retain some or all of their own social, economic, cultural, and political institutions; [or] self-identify as indigenous or tribal.

A key component of both definitions is historical continuity. According to Cobo (1983, pp. 50-51) historical continuity is determined by "occupation of ancestral lands, or at least of part of them, common ancestry with the original occupants of these lands, culture, language, residence in certain parts of the country, or in certain regions of the world, other relevant factors." The main shift from the ILO 107 to 169 definitions is prioritising free, prior and informed consent and emphasising the value of customary laws and ways of doing-rather than promoting assimilation. This shift arose, partially, from greater inclusion of Indigenous peoples in international decision-making and representation within international governmental organisations.

In 2007, the landmark UN Declaration on the Rights of Indigenous Peoples (UNDRIP) specifically recognised Indigenous peoples' right to self-determination through "autonomy, or self-government in matters relating to their internal and local affairs, as well as ways and means for financing their autonomous functions" (United Nations, 2007, p. 4). This right, however, was not without limitations. Indigenous peoples and the international community would need to agree on who is Indigenous (many states did not ratify ILO 169), what the right to self-determination meant in practice and how to navigate the lingering stranglehold of state and colonial power.

In terms of Indigenous and customary authorities specifically, UNDRIP makes several claims. First, Indigenous peoples have the "right to autonomy or self-government in matters relating to their internal and local affairs" (Article 4, p. 8) and can "maintain or strengthen their distinct political, legal, economic, social and cultural institutions" (Article 5, p. 9). They 
may determine the membership, structure, representatives and procedures of these and newly developed institutions (Article 18 and 33). However, these rights are mediated by a territorial integrity clause that prevents the use of Indigeneity to justify metropole separatist movements or even geographically near SNIJ independence movements. In addition, Articles 34 and 46 go on to say that customary institutions and activities must align with "international human rights standards" and "principles of justice, democracy, respect for human rights, equality, non-discrimination, good governance and good faith" (United Nations, 2007, pp. 24, 29). It is much less clear how these tenets might align with customary systems of governance. Some interpretations of Article 46 imply that it limits the ability or methods by which Indigenous peoples can claim their own rights and prevent any claim that would rely on an organisation not founded on western principles (Graff, 2012). The examples highlighted in this publication draw attention to cases where distinct Indigenous or customary authorities have potentially negotiated autonomy or sovereignty alongside local SNIJ and State governments.

\section{The inclusion of Indigenous and customary authorities in metropole-island relations}

Contemporary metropole-island associations that originate in colonial contexts exist between a variety of SNIJs and metropolitan states. To balance the requirements of diverse overseas populations, and islands that are both geographically close and distant, states employ flexible asymmetrical federal structures, place-specific disproportionate systems of representation and special rights (Baldacchino \& Milne, 2009). These unique metropole-island relations have fostered an Islandian sovereignty characterised by five features: 1) voting no in referendums on independence, 2) continuously negotiating "constitutional exceptions," 3) bending metropolitan laws or regulations, 4) receiving significant metropolitan budgetary support and 5) signing international treaties (Prinsen \& Blaise, 2017, pp. 64-67). Island studies and associated literatures have clearly documented the economic, political and social advantages of SNIJ status, which Baldacchino (2010, p. 193) claims are predicated on "relatively benign colonial relationships" (see: Armstrong \& Read, 2000; Baldacchino, 2004, 2006; Baldacchino \& Hepburn, 2012; Baldacchino \& Milne 2009; Betermier, 2004; Clegg, 2018; Connell, 1994, 2001; Dunn, 2011; Hintjens, 1997; McElroy \& Mahoney, 2000; McElroy \& Sanborn, 2005; Trompf, 1993). These benign relationships benefit both the SNIJ and the State. For example, A French diplomat in the Pacific described the collaboration between SNIJs and Paris as one of "bi-multilateralism" that increased France's regional clout as much as New Caledonia and French Polynesia (Lechervy, 2015, p. 108). However, the strategic benefits of SNIJ status and the efficacy of benign colonial relationships are beginning to be questioned, especially where Indigenous island populations continue to be marginalised.

According to Baldacchino and Milne's (2006) research, if islands, and their governing institutions, want to be treated like partners with the metropole they must have a strong island identity and the constitutional precedents for a sustained claim to self-government. Is it enough to establish a local government authority that includes customary representation or Indigenous politicians? A survey of SNIJs with resident Indigenous peoples revealed that very few have retained or established Indigenous or customary authorities, separate from local government authorities, even though the political capacities afforded to SNIJs include local autonomy. As SNIJs have negotiated greater sovereignty, in part, through Islandian 
sovereignty, some Indigenous or customary authorities have been established or re-established within new institutional frameworks.

In the context of this paper, we are concerned with SNIJs where distinct Indigenous or customary and local government authorities exist and negotiate sovereignty with metropolitan states (see Table 1). Using Stuart (2008) and Rezvani's (2014) lists of SNIJs as a starting point, we narrowed our focus to those SNIJs with Indigenous peoples, as defined in the ILO 169. The resulting list included many examples of SNIJs with legal pluralism and elements of customary governance or Indigenous representation embedded within local government authorities. Kalaallit Nunaat (Greenland), for example, is a self-governing SNIJ of Denmark, where all government representatives are Indigenous Kalaallit (Inuit) and is a representative democracy with a Premier appointed by the elected Parliament (Inatsisartut) and a cabinet of ministers (Naalakkersuisut) appointed by the Premier (Government of Greenland 2011). US overseas territories like Guam, Northern Marianas and American Samoa also have significant local autonomy and self-governance. However, in all of these cases, there is no distinct Indigenous or customary authority separate from the local government. In regards to local government authorities, we make a distinction between customary authorities or Indigenous authorities that incorporate elements of customary governance (i.e., voting protocols, leadership, their mandate, administration, etc.) and local government authorities (established as part and parcel of contemporary metropolitan administrative system and rooted in $19^{\text {th }}$-century colonialism). Hereafter, these local government authorities will be referred to as local metropolitan authorities. The examples we consider explore how sovereignty or an ever-expanding self-governance or local autonomy is negotiated among three main parties: the metropole, the local metropolitan authorities and an Indigenous or customary authority. These cases represent, at least in theory, state-to-state relations, where customary or Indigenous institutions are recognised as partners-not just as service providers but as 'sovereign' authorities negotiating their own form of Islandian sovereignty just shy of Westphalian sovereignty.

Defining a SNIJ for the purposes of this survey was nearly as difficult as determining which jurisdictions include Indigenous or customary authorities. Stuart's (2008) list of SNIJs is derived from Baldacchino's definition of SNIJs as: "non-sovereign states with strong levels of internal autonomy, whether de jure or de facto or both; sub-national entities associated to a larger sovereign state with a distinct society and culture and constitute islands" (Ackrén, 2018). These "non-sovereign island jurisdictions" (Baldacchino \& Milne, 2006, p. 487) also overlap with what Rezvani (2014, pp. 22-23) terms partially independent territories or "(1) nationalistically distinct entities that are (2) constitutionally unincorporated into the core state with which they (3) divide and share sovereign power." Based on these definitions, some island territories were rejected because they are fully integrated into the mainland state authority or are not substantially different from any other mainland administrative unit. In other cases where Indigenous or customary authorities distinct from local metropolitan authorities do exist, the populations are divided between mainland and island regions. Finally, we omitted cases where the local metropolitan authority is Indigenous because the majority of the population is Indigenous or a distinctly separate Indigenous or customary authority does not exist. What follows is a brief overview of the SNIJ authorities specified in Figure 1, the colonial context in which these authorities arose and, to the extent that current literature elucidates, an introduction to power sharing between authorities. 
Table 1. Multilateral negotiations in SNIJs.

\begin{tabular}{|c|c|c|c|}
\hline SNIJ & $\begin{array}{l}\text { Metropolitan } \\
\text { State }\end{array}$ & $\begin{array}{l}\text { Local Metropolitan } \\
\text { Authority }\end{array}$ & $\begin{array}{l}\text { Customary or Indigenous } \\
\text { Authority }\end{array}$ \\
\hline $\begin{array}{l}\text { Torres } \\
\text { Strait } \\
\text { Islands }\end{array}$ & Australia & $\begin{array}{l}\text { Torres Strait Island } \\
\text { Regional Council; } \\
\text { Torres Shire Council; } \\
\text { Northern Peninsula Area } \\
\text { Council }\end{array}$ & $\begin{array}{l}\text { Torres Strait Island Regional } \\
\text { Council Advisory Committee; } \\
\text { Torres Strait Regional Authority }\end{array}$ \\
\hline $\begin{array}{l}\text { Rapa Nui } \\
\text { (Easter } \\
\text { Island) }\end{array}$ & Chile & $\begin{array}{l}\text { Provincial and Municipal } \\
\text { Governments of Easter } \\
\text { Island }\end{array}$ & $\begin{array}{l}\text { Elders' Council } \\
\text { Rapa Nui Parliament }\end{array}$ \\
\hline $\begin{array}{l}\text { New } \\
\text { Caledonia } \\
\text { (Kanaky) }\end{array}$ & & Territorial Congress & Customary Senate \\
\hline Mayotte & France & Departmental Council & Islamic Qadis councils/magistrates \\
\hline $\begin{array}{l}\text { Wallis and } \\
\text { Futuna }\end{array}$ & & Territorial Assembly & $\begin{array}{l}\text { Chiefdoms: Uvea (Wallis); Sigave } \\
\text { (Futuna); Alo (Alofi) }\end{array}$ \\
\hline
\end{tabular}

Torres Strait regional authority and local councils in Australia

The Torres Strait Island (TSI) region includes dozens of islands spread across 48,000 kilometres of the Torres Strait between Australia and Papua New Guinea. The TSI did not experience a massive influx of settlers during colonisation; rather the island experienced an inflow of European and Pacific Islander traders and missionaries before it was annexed by the Queensland Government. Europeans were first recorded in the region in 1606 when the TSI population was estimated to be 4,500, but settlements were not established until 1788 (Beckett, 1987). Traffic through the region grew in response to booming peal shell and sea slug industries. Early relations between Torres Strait Islanders and other Pacific islanders were "defined in terms of kinship and affinity and sustained by the exchange of gifts" while relations with Europeans "were defined functionally and regulated by the workings of the market and the state" (Beckett, 1987, p. 32). In the late 1800s, the London Missionary Society settled on the islands, administering the region, converting islanders and serving as an intermediary for European commercial and political interests. Once the TSI were annexed by Queensland, between 1872 and 1879, a dual governing system was established: Torres Shire (local metropolitan authority) and individual Island Councils (Burton, 2019; Sanders \& Arthur, 2001). The Island Councils supplanted the "mamooses" system of island leaders and gave islanders control over local governance and justice (Torres Strait Island Regional Council, 2016). When the Aboriginals Protection and Restriction of the Sale of Opium Act came into force, it severely restricted this power, marginalising and disempowering TSI through strictly regulated aboriginal reserves (Torres Strait Island Regional Council, 2016). After it was repealed in 1939, islanders were legally recognised as a distinct peoples, and, in 1967, as citizens of Queensland (Beckett, 1987). 
Despite an unsuccessful bid for sovereignty, Islanders gained significant autonomy in the latter part of the $20^{\text {th }}$ century through association with Australia. In 1975, Islanders chose to remain associated with Australia, instead of aligning with the newly independent Papua New Guinea. By subsequently arguing that Indigenous peoples inhabited the islands prior to European settlement, the TSI gained both autonomy and the right to marine resources in the region (Grydehøj, Nadarajah \& Markussen, 2020). The Island Councils, which had occasionally come together as the state-sanctioned Island Advisory Council, became the Island Co-ordinating Council (ICC), the Torres Strait Regional Council and then the Torres Strait Regional Authority (Sanders \& Arthur, 2001). In the 1980s, the ICC advocated for sovereignty and powers equivalent to a State or Territory (Sanders \& Arthur, 2001). While this bid and the independence movement more broadly fell short of sovereignty, it did result in increased local autonomy.

The Torres Strait Islander Commission Act 1989 established the Torres Strait Regional Authority (TSRA), which has the authority to create and manage regional programmes for Torres Strait Islander and Aboriginal people living within the region, advise the Minister for Indigenous Affairs, and identify and uphold Ailan Kastom (Liu, 2012). Ailan Kastom or Island Custom is "the body of customs, traditions, observances and beliefs of Torres Strait Islanders generally or of a particular community or group of Torres Strait Islanders, and includes any such customs, traditions, observances and beliefs relating to particular persons, areas, objects or relationships" (Government of Queensland 2016, p. 83). Both a Commonwealth statutory authority and a form of Indigenous authority, the TSRA has a twenty-member political decision-making board, who are all Torres Strait Islander or Aboriginal people living in the SNIJ and elected by their individual communities.

In terms of local metropolitan authorities, the TSRA sits alongside three local councils that administer all inhabitants of the Torres Strait: the Torres Strait Island Regional Council (TSIRC), the Torres Shire Council (TSC) and the Northern Peninsula Area Council (NPARC). The councils are responsible for local law making and service provision for both Indigenous and non-indigenous inhabitants. Their administrative structure includes an elected Mayor and Councillors, a Chief Executive Officer and employees. TSIRC also includes a specialised Advisory Committee, with a Councillor and appointed members of the public, to advise the council on Island Custom and Lore.

Although the UNDRIP would not be supported by Australia until 2009, the establishment of TSRA, recognition of Ailan Kastom, and associated special advisory committees reflect a local application of the declaration's commitment to customary authorities. Initially, Australia voted against UNDRIP citing concerns about Article 3's acknowledgement of self-determination for all Indigenous peoples, superseding prior legal rights to land and private land ownership amongst the non-indigenous population, actualising free prior and informed consent, and irreconcilable differences between customary law and general rights (Anaya, Lenoir \& Rogers, 2009). This policy reversal, however, may reflect growing Aboriginal and Torres Strait Islander power through state and customary authorities - negating the state's original concerns with UNDRIP. That said, the state has yet to ratify the legally binding ILO 169 which would necessitate a closer consideration of mechanisms for free, prior and informed consent. 
Mahori Koranic law in Mayotte

Mayotte is a French Overseas Department (DOM) between Comoros and Madagascar. Unlike the other SNIJs in this survey, the Mahorais of Mayotte are not always recognised as Indigenous peoples. However, according to the definition provided in ILO 169, the Mahorais could constitute and Indigenous peoples given the colonial history of the island and their distinctive identity, traditions and customary institutions. Since the 1400s, Mayotte was invaded and settled by Arabs, Portuguese and French, and the Sakalava from Madagascar (Mayotte, 2019). This mix of cultures and ethnic groups is connected by a common religion and customary system. Currently, about 95\% of Mahorais are Sunni Muslim, a religion that has blended with strong animist belief systems - a product of the island's history. Linguistically, Mahorais fall into two categories: Bantu-based dialects and Malagasy dialects (Golembeski, 2012). Recent immigration has established new identity groups from France, Comoros, India, Madagascar and Réunion (Golembeski, 2012). Aside from the debate over whether Mahorais should be considered an Indigenous peoples, this example presents an opportunity to examine multilateral negotiations of Islandian sovereignty between and among the French State, local metropolitan authority and customary authorities and potentially draw comparisons with the customary components of Indigenous authorities elsewhere.

France established colonial control over the island in 1843 and Mayotte, together with Madagascar and Comoros, became an overseas territory of France until the late $20^{\text {th }}$ century (Mayotte, 2019). Following an independence referendum in 1974, 63.8\% of inhabitants voted for the island to remain French rather than join the newly independent Islamic Republic of the Comoros archipelago (Uimonen, 2014). Another vote, in 1975, confirmed the first result with 99.4\% voting for French administration. Mayotte's official status shifted from a Territorial Collectivity to a Departmental Collectivity in 2001. In 2011, 95.2\% of the population voted for the island to become a DOM. As a result, the local metropolitan authority includes a French-appointed Prefect, an elected Departmental Council and a French judicial system.

Mayotte's system of legal pluralism and customary law is comparable to New Caledonia. "The indigenous islanders of New Caledonia (South-West Pacific), Mayotte (Indian Ocean), and Wallis and Futuna (Central Pacific), are now France's only remaining citizens who are not subject to the Civil Code" (Trépied, 2016, p. 99). Article 75 of the 1958 French Constitution allows territories that are not subject to the Civil Code to maintain personal law systems or statut personnel (Daly, 2015). Mahorais adherents to the statut personnel are governed by a "hybrid of Malagasy and East African customary law, mixed with elements of Islamic law," which includes the right to practice polygamy and matrilineal inheritance (Daly, 2015, p. 541; Uimonen, 2014). This customary legal system is arbitrated by Tribunals of Cadi, with an appeals court overseen by the Great Cadi and the Muslim Cancelling Chamber (Blanchy \& Moatty, 2012). Prior to 2011, the Cadi administered about one-third of the population, serving "judicial, notary and social and administrative functions" including "religious proxy, donations, partition of property, acts of sale, and certificates and settlements of inheritance" and "mediation and moral and religious authority" (Uimonen, 2014, p. 462). The Cadi were typically contract based and appointed by a prefect with input from representatives from the French state, a committee and the religious community (Uimonen, 2014).

Unlike the Pacific SNIJs, in Mayotte, customary rights and the power of the Cadi as an authority began disappearing after the island transitioned to a DOM. These changes imposed 
by the French state are partly a result of the perceived irreconcilable differences between Mahori Koranic law and the accepted administration of DOMs (Trepied, 2012). The process of disempowering customary leaders and their practices started with an earlier judgment from the Constitutional Court affirming that the lawmakers are able to adapt the statut personnel "to adjust to the principles and rights constitutionally protected" (Loi de programme, 2003). Mahoris could now permanently renounce their statut personnel. These and other laws have gradually undermined the cadis, who increasingly serve as ill-defined mediators (Hachimi \& Lemercier, 2018). Publicly, Mahoris support association with France. However, this desire sits alongside a strong tradition of Islamic customary practice within the private sphere and structured around the family unit (Blanchy, 2002). Challenges remain in this society, where identity and Islam are closely intertwined alongside the French administrative status chosen by the population.

Like Australia, France has yet to ratify ILO 169. However, it was an early adopter of UNDRIP and despite similar concerns about self-determination, voted in favour of the declaration. France's concerns with the declaration parallel the republican ideals that underpin scepticisms around the incorporation of a DOM with a majority Muslim population. For overseas collectives, like Mayotte, French citizenship presents an irreconcilable dichotomy: it avoids identity categorisations, but predicates political belonging on an individual's ability to overcome their cultural background (Daly, 2015). In the case of legal pluralism in Mayotte, this dichotomy "demonstrates the paradoxically communitarian logic that underlies the universalist discourse; in order to be granted an unalloyed and equal status with the Republic, the peripheral and ex-colonial territories must first achieve a certain cultural assimilation to the metropole" (Daly, 2015, p. 544). Indeed, the French state was careful to adopt the principles of self-determination outlined in UNDRIP only as their Constitution allows for overseas territories and is careful to ensure that collective rights do not undermine individual rights (Anaya et al., 2009). The tension between special collective rights or customary rights and French civil law is a common point of contention among other overseas collectives.

\section{Indigenous authorities in Rapa Nui (Easter Island)}

Rapa Nui (Easter Island), between Pitcairn Island and Chile, was settled by Polynesian peoples, whose political structures included lineage groups (hua'ai) organised in two confederacies of matas (tribal territories), under the nominal leadership of a paramount chief (ariki). The essential elements of this structure-two confederacies of matas called mata nui and mata iti-are still used today (Teave \& Cloud, 2014, p. 405). Visits by European ships in the $18^{\text {th }}$ century left no lasting impact, but in the early 1860 s, Peruvian slavers kidnapped and murdered most of the islanders, while infectious diseases killed many others. French Catholic missionaries from Tahiti arrived in the late 1860s and attempted to get France to declare the island a French protectorate, but these attempts failed. By the early 1870s, the population was estimated to have been reduced to no more than 200 people, with structures of Indigenous authorities severely impaired (Gonschor, 2011).

Missionaries from Chile's Catholic Church arrived in 1870 and constituted the first Chilean interest in Rapa Nui. A Chilean navy captain travelled to Rapa Nui and Tahiti in 1887 and 1888 to purchase all land claims by European missionaries and settlers for the Chilean state. The relationship between the Chilean state and twelve representatives of the remaining Indigenous authorities of Rapa Nui and were captured in an 1888 Agreement of 
Wills (Acuerdo de Voluntades) signed in two languages: Spanish and Rapa Nui. While the Spanish version talks of the islanders ceding sovereignty to Chile, the Rapa Nui language version merely cedes the right "to be a friend of the island" (Pereya-Uhrle, 2005, p. 135). In this light, it can be argued that the Rapa Nui Indigenous authorities now merely sought to be a protectorate from Chile, as they have done at least three times earlier from France (Gómez, 2010, p. 70). However, from a Chilean State perspective, the 1888 Agreement effectively underpinned the annexation of the island.

Between 1888 and 1966, the Chilean state did not engage in any negotiations with Rapa Nui's Indigenous authorities. In 1895, the Chilean state leased most of the island to a commercial company as a sheep farm, while forcing all Rapa Nui people to live in an enclosed area around the principal village of Hanga Roa. The company's lease was renewed repeatedly until 1953 when the state took over the farm, while the Chilean state changed the legal status of the island in 1917, 1933 and 1935-when it was declared a National Park-without any form of consultation or even information towards Rapa Nui Indigenous authorities (PereyaUhrle, 2005).

In the 1960s, progressive politics came to the fore in Chile and the state began to engage with Rapa Nui Indigenous authorities. The 1966 Easter Island Law gave Rapa Nui people citizenship, the right to vote and the entitlement to public health and education services. For the first time, consultative commissions were created between state representatives and Indigenous authorities to discuss protection of the island's unique archaeological heritage, natural resources and cultural practices. However, while the 1966 Law created a legal framework for Rapa Nui people to own land, in practice no Rapa Nui people acquired legal land rights - either as individuals or as one of the 36 lineage groups, hua 'ai. The 1973 military coup ended the dialogue, but its drive to privatise the Chilean economy also saw it move to offer permanent land titles to individual Rapa Nui people. More than a thousand Rapa Nui people sought individual titles, in face of strong protests by other Rapa Nui people (Gonchor, 2011). In 1979, these tensions led to the establishment of the Rapa Nui Council of Elders (Consejo de Ancianos). The council included representatives from each hua'ai for a lifetime term. "The council's purpose is to defend the Rapanui's right to their land and territory, their culture and traditional social organisations" (Delsing, 2015, p. 80).

As military rule was replaced by civilian government in 1989, formal negotiations between Rapa Nui's Indigenous authorities and the State resumed, with a 1993 Indigenous Law formally recognising the existence of Indigenous peoples in Chile and the state's duty to promote and protect Indigenous rights, culture and lands. For Rapa Nui island, the 1993 Law not only meant the formal recognition of the Rapa Nui Council of Elders, but also the establishment of the Commission for the Development of Easter Island (Comisión de Desarrollo de Isla de Pascua or CODEIPA). CODEIPA was mandated to make wide-ranging proposals about governance and resource management in Rapa Nui and membership is divided evenly among officials representing the Chilean state, elected Rapa Nui people and the president of the Rapa Nui Council of Elders. "It is the first time elected Rapanui take active part in the decision-making process on a regular basis and in on-island meetings" (Delsing, 2015, p. 99). However, it should be noted that the institutions resulting from the 1993 Indigenous Law are created by the Chilean State and not negotiated with Rapa Nui people. In fact, it has been argued the law "is not consistent with the standards in international law with regard to the 
rights of indigenous peoples" (Silva Neriz, 2013, 188). This leaves this institutions primarily oriented towards the State. The National Indigenous Development Corporation (CONADI), for example, has as one of its functions "the restoration of ancestral lands that have been taken away from indigenous peoples," but it has limited its activities to irrigation infrastructures (IWGIA, 2012, p. 10). The negotiations between Rapa Nui people and the Council of Elders and the Chilean state within the framework determined by the state's CODEIPA and associated legislation have revealed divided opinions among Rapa Nui people with regards to the future. By the mid-1990s, the Council of Elders split over diverging views on land ownership. A Council Number Two (Consejo Dos) was formed by dissident members who emphasised democratic elections based on individual voting, rather than hua 'ai-based lifetime membership. By the early 2000s, Council Number Two renamed itself the Rapa Nui Parliament (Parlamento Rapa Nui) and began advocating "our autonomy via the creation of our own structures of governance" (Constitución Parlamentaria 2001)" (cited in Delsing, 2015, p. 132). Throughout the 2000s, the Council of Elders and CODEIPA began providing land titles to both individuals and families or hua "ai, with additional financial resources made available to facilitate "the transfer of [land] titles over private land to indigenous people" (Pereyra-Uhrle, 2005, p. 141).

By the early 2010s, the negotiations or confrontations between Rapa Nui people and the Chilean state not only continued on two tracks - via the Council of Elders and the Rapa Nui Parliament - but also expanded into fields of sovereignty hitherto untouched. This may have partially been a product of Chile's adoption of UNDRIP or ratification of ILO 169 one year later. However, an IWGIA report (2012) noted, "an elder of the Rapa Nui Parliament told us that the right to prior consultation and consent that is stipulated in ILO Convention 169 of the ILO makes sense to them, but that State actions have not been consistent with this." Publicly, the state acknowledged a need to develop mechanisms for consultation with Indigenous peoples throughout Chile (Anaya et al., 2009). Meanwhile, the Rapa Nui Parliament staged the coronation of a descendant from the last Rapa Nui king in front of the Governor's Office- to which the governor as the representative of the Chilean state and a Rapa Nui person, responded by singing along with the coronation songs (Young, 2013). The balance of power over control of land and natural resources seemed to begin shifting towards Rapa Nui island. Aside from many Rapa Nui people now having access to land titles, the 'co-administration' of the National Park shifted to full Indigenous administration in 2017 (Young, 2019).

At a political level, in 2013, the Rapa Nui Parliament organised its first elections for 1,800 registered Rapa Nui voters. The public debates appeared to reveal a shift from land rights to immigration from mainland Chileans. About $60 \%$ of the 6,000 people in the island are Rapa Nui people, the others are immigrants from Chile (IWGIA, 2019, p. 7) and about half of the Rapa Nui people live in Chile (Muñoz, 2014, p. 29). Both leading candidates agreed immigration needed to be stopped (Young, 2015, p. 282). By 2018, Chile had approved a special Residential Law (Ley de Residencia) controlling entrance and immigration into Rapa Nui island. All visitors' stays are now limited to 30 days and even Chilean nationals are subject to the new law, leaving settlement to the island only open to family of people already resident on the island (Young, 2019). 


\section{Chefferies à titre in Wallis and Futuna}

Prior to colonisation, South Pacific islands Wallis and Futuna had intricate systems of Indigenous authorities that were rather distinct, due to different engagements with Tonga and Samoa as regional political powers (Burrows, 1936, 1937). In the late 1830s, French missionaries arrived and within a few years succeeded in converting the islanders to Catholicism, exerting influence over Indigenous authorities. Records suggest the three kingdoms wrote formal requests to become a protectorate of France in 1842, which had no real consequence in terms of a presence of the French state on the islands. However, a repeated request by Wallis's Queen Amelia in 1886 was formalised in an official treaty in 1887. This treaty stated the Queen accepted a French Resident to decide external affairs and for dealing with Europeans in the island, while the Queen maintained authority over the island's population. The French Resident was given a seat in the Queen's Council. Similar agreements were proposed and agreed by Futuna's kings in 1888. Soon after, Paris turned both islands into a single protectorate. A 1913 decision by the French Minister of Colonies formally transformed the protectorate into an annexation (Angleviel, 1994).

When Wallis and Futuna became a French overseas Territory in 1961, their relationship with France was formalised through the Statut de 1961 (or statute). Part of the document recognised France's respect for custom. Article 3 mentions that "the Republic ensure to inhabitants from Wallis and Futuna respect to their beliefs and customs as long as they are not opposed to general legal principles and to the current law" (Joissains \& Sueur, 2014, p. 16). Social organisation was still very much oriented around relationships to the royal family and political institutions were organised according to French standards. However, existing land divisions that corresponded to traditional family partitions were included. As a result, the socalled French authorities were trusted representatives elected from among the Indigenous peoples. Joissains and Sueur (2014) argue that this statute is a success precisely because there are not two distinct structures of authorities. Instead, customary authorities and customary practices have been formally incorporated into, or co-exist in parallel to, the local metropolitan authorities.

Today, the rights of island inhabitants are jointly governed by droit commun (common law) and a customary Wallisian and Futunan justice system called droit coutumier (customary law) (van der Grijp, 2005). While France seems reluctant to support the tenets of UNDRIP by ensuring the continuation of customary law in Mayotte, the Indigenous customary authorities and leaders of Wallis and Futuna are empowered to "oversee customary matters and three customary representatives (kings or chiefs), alongside the prefect, take part in the Territorial Committee where they can approve or reject projects before they are considered by the administration and the territorial assembly (IEOM, 2015)" (Jacobs \& Overton, 2017, p. 155). In Futuna specifically, chefferies à titre (Sigave and Alo) exist parallel to Western political institutions (Favole, 2007). "The two local chiefdoms (pule'aga sau in Futunan) are confederations of chiefs (aliki), divided into village chiefs (aliki pule kolo) and district chiefs (aliki lasi): the king ( $\mathrm{Sau}$ ) is the supreme authority, not in the sense of holding oligarchic and pyramidal power but as the 'symbol' of the chiefdom and the trait-d'union between the various leaders (Favole, 2000)" (Favole \& Giordana, 2018, p. 212).

The borders of the two chiefdoms correspond to the French administrative boundaries and the two Sau (kings) sit on the Territorial Council (Favole \& Giordana, 2018). The local metropolitan authority, or Territorial Council, includes a Prefect, the Prefect's Delegate, two 
Sau (kings) from Futuna and the Laveluea (king) from Wallis and three other representatives appointed by the Prefect (Favole \& Giordana, 2018). The Territorial Assembly, in comparison, comprises twenty elected representatives, thirteen from Wallis and seven from Futuna (Favole \& Giordana, 2018). The mediating factor in the realisation of UNDRIP in this case is spatial. Customary status and the associated rights, under French law, are limited to one's home country. As with the state's comments on the declaration, here is a specific example of how France treats each overseas collectivity, and Indigenous group, differently. As a result, the mass migration of Wallisians and Futunans to places like New Caledonia have restricted their customary rights. Many now seek to retain their customary status, while continuing to reside in New Caledonia, parallel to Kanak customary status (Trepied, 2012).

\section{Customary Senate in New Caledonia (Kanaky)}

In New Caledonia, Indigenous Kanak have been arguing for independence based on distinctive identity since the 1960s (Trepied, 2012). However, "claims based on autochtonie for the recognition of distinct peoples within the French Republic, are considered incompatible, by law, with the notion enshrined in the Preamble and Article 3 of the French Constitution" (Mrgudovic, 2012, p. 457). The French State did revise the Constitution in 1998, after signing the Nouméa Accord, which acknowledges the Kanak as a distinct Indigenous group. Currently, the Constitution recognises the Kanak as distinct with the right to claim their independence, but also expresses overseas territories' right to self-determination via "new institutions founded on the common ideal of liberty, equality and fraternity and conceived for the purpose of their democratic development" and claims that no individual or subnational population can claim national sovereignty (Loi Constitutionnelle, 1998). As Anaya et al (2009) pointed out, the French State applies UNDRIP only as the current interpretation of the constitution allows-protecting the state's interests in a unified France. How, then, have French SNIJs established Indigenous authorities and legal pluralism?

In the context of UNDRIP, France made it very clear that claims to sovereignty made on behalf of Indigenous peoples would only apply to overseas territories-restricting access for metropole separatist groups or 'near' islands like Corsica (Trepied, 2012). However, the shift in international norms from decolonisation as independence to more creative forms of shared sovereignty have resulted in particular metropole-island relations between France and its Pacific SNIJs (Mrgudovic, 2012). As Le Meur (2015, p. 238) points out, “the UN's golden rule of non-interference further contributed to the shift from independence claims to internal self-determination claims." Indigenous people are trying to overturn this 'golden rule' by actually seeking a relationship with the metropole and/or international organisations in a way that interferes in their relationship with local authorities on SNIJs. In New Caledonia, the French state is sometimes viewed as a mediator and called in to arbitrate internal tensions, to maintain peace and ensure safe elections and negotiations. As a result, some factions within New Caledonia consider the French state a necessary intermediary in internal SNIJ political relations (Korson, 2015). In addition, the shift from sovereignty to autonomy, and to some point even French support for customary governance and law, has been a way for the metropole to retain this position (Graff, 2012; Monnerie, 2003).

For Kanak leaders, the Matignon and Nouméa Accords opened up new possibilities whereby the recognition of Indigenous Kanak identity can be used to access particular rights and powers. The Matignon Accord established a customary council, the precursor to the 
Customary Senate formed under the Nouméa Accord. The creation of this institution, even in an advisory capacity, was a step towards recognising the Kanak as a partner in negotiations over the future of New Caledonia (Le Meur, 2015). The Nouméa Accord (1998) established statut coutumier or a customary status that sits alongside droit commun (common law). The Customary Senate includes two representatives from each of the eight customary regions and is concerned with laws related to Kanak identity, the "harmonization between French law and customary law," the "customary register of land property" and management of natural resources (Palayret, 2004, p. 228). Senators are appointed by each of the eight regional customary councils who are themselves appointed according to custom in each area (Les conseils coutumiers, n.d.). The power of the Customary Senate is limited, but when the senate votes against a draft law put before it, the New Caledonian Congress must deliberate a second time (Ziller, 2009). UNDRIP established a framework for what Cornut (2018) calls 'coexistence' between customary and common law in New Caledonia. In his view, the two distinct sources must work together as the legitimacy of legal decision-making relies on both the inclusion of custom and common law's capacity to incorporate customary principles. Indeed, the Nouméa Agreement sets up collegiality as a way to allow all parties access to power and established special provisions for the Kanak population (Journal Officiel de la République Française 8039, 1998).

Customary law, Kanak identity and customs are undergoing a process of reconceptualisation precipitated by decolonisation, revitalised by Indigenous rights discourses and parallel to debates over sovereignty (Le Meur, 2015). While the Customary Senate has developed the Charter of the Kanak People, outlining custom and customary values, it has been critiqued for its paternalism and conservative approach (Demmer \& Salomon, 2013). Furthermore, the 'customary' discourse has become banalised and used to unite groups of indigenous people who were actually very different from each other. As such, customary became more of an identity indicator than representative of a series of traditional practices (Graille, 1999). “In this new 'customary-indigenous' perspective, official recognition of the Kanak people is no longer seen as a stage in a long struggle for independence, nor an arrangement that is inseparable from the project of citizenship and decolonisation, but simply as the local application of international principles for protecting indigenous peoples, independently of the question of independence" (Trepied, 2012, p. 14).

On 4 November 2018, nearly $81 \%$ of eligible voters turned out for the first of three possible referenda on independence, as required by the Nouméa Agreement. About 56.7\% of the population voted 'No' and $43.3 \%$ voted 'Yes' to the fundamental issue of whether inhabitants want to remain French or access full sovereignty. The significant number of votes in favour of full sovereignty surprised both loyalists and nationalists. Pierre-Christophe Pantz (2018) wrote in Le Monde that the results would force loyalists to review their position and speeches. Indeed, the results show that it is not only the Kanak population, likely with customary status, who answered 'Yes' to the full-sovereignty question. Support for the 'yes' vote might be the result of a strong redefinition of identity in New Caledonia.

Establishing customary institutions that acknowledge Kanak in the SNIJ's political organisation and making decisions in line with the essentials of Kanak identity was a required step in the process of recognising Kanak as an Indigenous peoples. The Customary Senate and other Indigenous authorities in New Caledonia exemplify the principles of UNDRIP in this way. Nevertheless, there is also parallel growth amongst Kanak representation in the local 
metropolitan authorities: the Government, the Territorial Congress and the Provincial Assemblies. As such, there is an appropriation of colonial political institutions and their practices, which are tinged with customary practices (i.e., palabra (talking) in the Territorial Congress). However, the role of Indigenous Kanak authorities is still more symbolic, more practical, than functional. It seems as though the Kanak have accumulated more rights and autonomy by embedding themselves in the political institutions that govern existing dynamics between the metropole and local metropolitan authorities, where their voice is better heard. The referendum is thus the political translation of a broader, societal process of redefining a society, which has yet to be analyzed as such. As New Caledonia faces the possibility of a second independence referendum, the role of the Customary Senate and the future of customary status bears even closer consideration for the ways in which metropole-islandIndigenous relations play out in the negotiation of sovereignty.

\section{Conclusions}

The ways in which Article 4 of UNDRIP - the "right to autonomy or self-government in matters relating to their internal and local affairs" - has been implemented varies greatly across SNIJs. In addition, internal inequalities within SNIJs raise important questions about whether Indigenous islanders experience the benefits of SNIJ status to the same extent, and in the same way, as non-Indigenous inhabitants. Using the cases of Hawai'i and Corsica, Androus and Greymorning (2016) contend that the benefits of non-sovereignty, economic and otherwise, must be examined comparatively among different ethnic groups within an island or archipelago, for example, the ways in which Chamorro have been marginalised through voting rights in Guam or the desire for independence or stronger mainland-island relations among peripheral archipelagic islands (Favole \& Giordana, 2018; Pöllath 2018).

Beginning with a broad definition of SNIJs, we narrowed our focus to islands with distinct Indigenous or customary authorities, separate from local metropolitan authorities. Of the 120 or so islands, we identified 5 SNIJs that met these criteria. The amount written about these Indigenous or customary authorities varies dramatically and scant literature discusses how they have negotiated autonomy or sovereignty within the context of metropole-SNIJ relations. This article, and the cases identified, offer a starting point for examining how Indigenous peoples, through Indigenous and customary authorities in particular, have exercised their right to self-determination and negotiated unique forms of sovereignty. We orient these cases in comparison with SNIJs where the local metropolitan authority is required to include Indigenous representation within the institution or is comprised of Indigenous peoples because they make up the demographic majority. Setting them apart offers the basis for a more detailed comparison of the way in which each of these cases negotiates sovereignty through multilateral relations between and among metropolitan states, local metropolitan authorities and (where applicable) distinct Indigenous or customary authorities.

Through the survey process, we found that many of the SNIJs with Indigenous peoples have no distinct Indigenous or customary authority that exists alongside local metropolitan authorities. Instead, Indigenous peoples, customary law and institutions and special rights are typically embedded within local metropolitan authorities. That said, these Indigenous groups have been able to appropriate or achieve significant representation within those metropolitan authorities and 'own' them for local matters (i.e., Kalallit Nunaat or Greenland). This 
resonates with parallel shifts in autonomy narratives and sense of belonging: from solely Indigenous to a more collective distinction between SNIJ inhabitants and the metropolitan state. Nevertheless, differences in metropole-Indigenous relations are intimately tied to the legal frameworks that underpin them. In contrast, the five cases we outlined represent distinct Indigenous or customary authorities entangled in complicated negotiations for sovereignty and customary governance and law. They work alongside and in contradiction to metropolitan states and local metropolitan authorities or international bodies and they use their unique position (straddling traditional Western and customary political and legal systems) to gain greater autonomy.

Establishing customary authorities and reasserting traditions often coincide with the recognition of Indigenous identity and negotiations over sovereignty and independence (Graff, 2012). This process of identity construction is negotiated and reconceptualised based on "changing histories, cultures and relationships to the land, leading to continued renegotiations of place" (Grydehøj et al., 2018, p. 5). The distinctive spatiality of islands and the ability of Indigenous peoples to ground their identity in that islandness has often been considered a benefit for justifying autonomy and sovereignty. However, there is a danger with combining Indigeneity and the island imaginary. If Indigenous peoples move beyond the bounded space of the island, their claims to Indigenous rights and Indigenous identity itself may be de-legitimised (Grydehøj et al., 2018). Certainly, customary status in Wallis and Futuna and the Torres Strait Islands reiterate the place-based nature of special customary rights: rights connected to the territorial extent of the archipelago. While this issue is not unique to island-based Indigenous peoples, it does add complexity to multilateral negotiations for autonomy or sovereignty. In the TSI, for example, the independence movement highlighted key divisions between islanders living in the homeland and those living in mainland diaspora: raising questions about representation and who has the right to speak (Liu, 2012). The Aboriginal and Torres Strait Islanders Act 2005 simultaneously undermined the representation of mainland islanders and affirmed the autonomy of islanders living in the TSI (Liu, 2012). In the case of Mayotte and New Caledonia, the will of the metropole to acknowledge and expand the power of customary authorities is linked to the degree of adjustment possible between customary and French law and principles of good governance. Each of the cases outlined here begins to unpack the multilateral negotiations of power between and among states, local metropolitan authorities and Indigenous or customary authorities within the unique purview of SNIJ relations.

\section{References}

Ackrén, M. (2018). Autonomous island regions, 50 Shades of Federalism. Retrieved from http://50shadesoffederalism.com/case-studies/autonomous-island-regions/

Anaya, S.J., Lenoir, J.J., \& Rogers, J.E. (2009). International human rights and Indigenous peoples. New York: Aspen.

Androus, Z., \& Greymorning, N. (2016). Critiquing the SNIJ hypothesis with Corsica and Hawai'i, Island Studies Journal, 11(2), 447-464.

Angleviel, F. (1994). Les missions à Wallis et Futuna au XIXe siècle (No. 18). Presses Universitaires de Bordeaux. 
Armstrong, H.W., \& Read, R. (2000). Comparing the economic performance of dependent territories and sovereign micro-states, Economic Development and Cultural Change, 48, 285-306. https://doi.org/10.1086/452459

Baldacchino, G. (2017). Autonomy plus: The policy challenges and opportunities faced by subnational (mainly island) jurisdictions. In W. Sheng, D. Zhen, J. Randall, L. Brinklow, \& J. Sinclair. Annual report on global islands 2017 (pp. 99-117). Charlottetown: Island Studies Press.

Baldacchino, G. (2010). 'Upside down decolonization' in sub-national island jurisdictions: Questioning the 'post' in postcolonialism, Space and Culture, 13(2), 188-202. https://doi.org/10.1177\%2F1206331209360865

Baldacchino, G. (2006). Managing the hinterland beyond: Two, ideal-type strategies of economic development for small island territories, Asia-Pacific Viewpoint, 47, 45-60. http://doi.org/10.1111/j.1467-8373.2006.00295.x

Baldacchino, G. (2004). Autonomous but not sovereign? A review of island sub-nationalism, Canadian Review of Studies in Nationalism, 31, 77-89.

Baldacchino, G., \& Hepburn, E. (2012). A different appetite for sovereignty? Independence movements in subnational island jurisdictions. Commonwealth \& Comparative Politics, 50(4), 555-568. https://doi.org/10.4324/9781315541228

Baldacchino, G., \& Milne, D. (Eds.). (2009). The case for non-sovereignty: Lessons from subnational island jurisdictions. Routledge: London \& New York.

Baldacchino, G., \& Milne, D. (2006). Exploring sub-national island jurisdictions: An editorial introduction, The Round Table, 95(386), 487-502. https://doi.org/10.1080/00358530600929735

Beckett, J. (1987). Torres Strait Islanders: Custom and colonialism. Cambridge University Press: Cambridge.

Betermier, S. (2004). Selectivity and the economics of independence for today's overseas territories, Explorations: The UC Davis Undergraduate Research Journal, 7, 63-85.

Blanchy, S. (2002). Mayotte «française à tout prix» Ethnologie française, nouvelle serie Outremers: Statuts, cultures, devenirs, 32(4), 677-687. https://doi.org/10.3917/ethn.024.0677

Blanchy, S., \& Moatty, Y. (2012). The civil status of local law in Mayotte: A sham? Law and Society, 80(1), 117-139. https://doi.org/10.3917/drs.080.0117

Burrows, E.G. (1937). Ethnology of Uvea (Wallis Island), (Vol. Bulletin 145). Honolulu: Bernice P. Bishop Museum.

Burrows, E.G. (1936). Ethnology of Futuna (Vol. Bulletin 138). Honolulu: Bernice P. Bishop Museum.

Burton, J. (2019). History of the Torres Strait up to full annexation in 1879. Torres Strait Regional Authority. Retrieved from http://www.tsra.gov.au/the-torresstrait/general-history\#TS\%20in\%20the\%201800s

Clegg, P. (2018). The United Kingdom and its Overseas Territories: No longer a 'benevolent patron'? Small States and Territories, 1(2), 149-168.

Cobo Martinez, J.R. (1983). Study of the problem of discrimination against Indigenous peoples. United Nations Economic and Social Council, E/CN.4/Sub.2/1983/21/Add.8. 30 September. Retrieved from https://www.un.org/esa/socdev/unpfii/documents/MCS xxi xxii e.pdf 
Connell, J. (2001). Eternal empire: Britain's Caribbean colonies in the global arena. In A.G. Ramos, \& A.I. Rivera (Eds.). Islands at the crossroads (pp. 115-135). Kingston: Ian Randle.

Connell, J. (1994). Britain's Caribbean colonies: The end of the era of decolonization, The Journal of Commonwealth and Comparative Politics, 32, 87-106. https://doi.org/10.1080/14662049408447675

Cornut, E. (2018). Intégration directe ou indirecte de la coutume dans le corpus normatif de la Nouvelle-Calédonie. General Report in La coutume kanak dans le pluralisme juridique calédonien, pp. 488-540. https://doi.org/10.3917/ethn.181.0057

Daly, E. (2015). Reframing the universalist Republic: Legal pluralism in the French periphery, Social \& Legal Studies, 24(4), 531-553. https://doi.org/10.1177/0964663915573043

Declaration on the granting of independence to colonial countries and peoples (1960). United Nations General Assembly, 14 December. Retrieved from https://www.un.org/en/decolonization/declaration.shtml

Delsing, R. (2015). Articulating Rapa Nui: Polynesian cultural politics in a Latin American nationstate. Honolulu: University of Hawai'i Press. https://doi.org/10.21313/hawaii/9780824851682.001.0001

Demmer, C., \& Salomon, C. (2013). Droit coutumier et indépendance Kanak-L’Écriture d'un droit coutumier: Une volonté partagée par l'ensemble des Kanak? Vacarme 3, 6378. https://doi.org/10.3917/vaca.064.0063

Dunn, L. (2011). The impact of dependence on small island jurisdictions. World Development, 39(12), 2132-2146. https://doi.org/10.1016/j.worlddev.2011.04.002

Favole, A. (2007). Démocratie et coutume à Futuna. La Ricerca Folklorica, 55, 109-122. DOI: https://doi.org/10.2307/30033333

Favole, A., \& Giordana, L. (2018). Islands of islands: Responses to the centre-periphery fractal model in East Futuna (Wallis and Futuna) and the Belep Islands (New Caledonia). Island Studies Journal, 13(1), 209-222. https://doi.org/10.24043/isj.42

Golembeski, D. (2012). Mayotte: France's new Overseas Department in the Indian Ocean, The French Review, 85(3), 440-457.

Gómez, R.A. (2010). Rapanui and Chile, a debate on self-determination: A notional and legal basis for the political decolonisation of Easter Island. Victoria University of Wellington: Wellington. Retrieved from http://hdl.handle.net/10063/1504

Gonschor, L. (2011). Facing land challenges in Rapa Nui (Easter Island). Pacific Studies, 34(2), 175-194.

Government of Greenland (2011). Final draft for the United Nations' universal periodic review $11^{\text {th }}$ session: Reporting on Greenland. United Nations.

Government of Queensland (2016). Acts Interpretation Act 1954. Retrieved from https://www.legislation.qld.gov.au/view/pdf/inforce/2016-03-22/act-1954-003

Graff, S. (2012). Quand combat et revendications Kanak ou politique de l'État Français manient indépendance, décolonisation, autodétermination et Autochtonie en Nouvelle-Calédonie. Journal de la Société des Océanistes, 134(1), 61-83. https://doi.org/10.4000/jso.6647 
Graille, C. (1999). Coutume et changement social en Nouvelle-Calédonie. Journal de la société des Océanistes, 109(2), 97-119. https://doi.org/10.3406/jso.1999.2108

Grydehøj, A., Nadarajah, Y., \& Markussen, U. (2020). Islands of indigeneity: Cultural distinction, Indigenous territory and island spatiality. Area, 14-22. https://doi.org/10.1111/area.12520

Hachimi, A.M., \& Lemercier, É. (2018). What to do with the cadis of the Republic: Investigation on the reconfiguration of the legal institution in Mayotte. French Ethnology, 169(1), 37-46.

Hintjens, H.M. (1997). Governance options in Europe's Caribbean dependencies. The Round Table, 344(1), 533-547. https://doi.org/10.1080/00358539708454387

IEOM (2015). Wallis-et-Futuna Rapport Annuel 2014. Nouméa, New Caledonia: Institut d'Emission d'Outre-Mer.

International Labour Organisation (1957). Indigenous and tribal populations convention no. $107 . \quad$ Retrieved from https://www.ilo.org/dyn/normlex/en/f?p=NORMLEXPUB:12100:0::NO::P12100 ILO CODE:C107

International Labour Organisation (1989). Indigenous and tribal peoples convention no. 169, $27 \quad$ June. Retrieved from http://www.ilo.org/dyn/normlex/en/f?p=NORMLEXPUB:12100:0::NO::p12100 instrument id:312314

IWGIA (2012). The human rights of the Rapa Nui people on Easter Island (IWGIA Report 15). Report of the international Observers' Mission to Rapa Nui 2011. Copenhagen: IWGIA. https://doi.org/10.1080/00358539708454387

IWGIA (2019). Rapa Nui. In International Work Group for Indigenous Affairs (IWGIA) (Ed.). Indigenous peoples rights to self government as a manifestation of the right to selfdetermination (pp. 7-9). Copenhagen: IWGIA. https://doi.org/10.1017/s0032247400012882

Jacobs, A., \& Overton, J. (2017). Tout la monde a sa place? MIRAB, education, and society in Wallis and Futuna. Island Studies Journal, 12(1), 151-168. https://doi.org/10.24043/isj.10

Joissains, S., \& Sueur, J.P. (2014). Les îles Wallis et Futuna: Assurer le développement dans le respect des spécificités locales. Rapport d'information de Mme Sophie Joissains et M. Jean-Pierre Sueur, fait au nom de la commission des lois $\mathrm{n}^{\circ} 103,19$ November. https://doi.org/10.3917/tdm.023.0026

Journal Officiel de la République Française 8039 (1998).Nouméa Accord, 27 May. Retrieved from https://www.legifrance.gouv.fr/jo pdf.do?id=JORFTEXT000000555817

Korson, C. (2015). Mapping Narratives of Self-determination, National Identity and (Re)balancing in New Caledonia (Doctoral Dissertation, Kent State University).

Lechervy, C. (2015). L'intégration régionale de la France dans le Pacifique océanien, une diplomatie multimodale. Journal de la Société des Océanistes, 140(1), 105-121. https://doi.org/10.4000/jso.7282

Le Meur, O. (2015). Customary law and custom in New Caledonia: Legal pluralism, citizenship and the external/internal sovereignty issue. SOAS Law Journal, 2(1), 230259. 
Les conseils coutumiers (n.d.). Le Sénat Coutumier. Retrieved from http://www.senatcoutumier.nc/aires-coutumieres/les-conseils-coutumiers

Loi Constitutionnelle nº98-610 relative à la Nouvelle-Calédonie (1998). Titre XIII de la Constitution, 20 July. Retrieved from https://www.conseil-constitutionnel.fr/lesrevisions-constitutionnelles/loi-constitutionnelle-n-98-610-du-20-juillet-1998

Loi de programme pour l'outre-mer (2003). Décision n² 2003-474, 17 July. Retrieved from https://www.conseil-constitutionnel.fr/decision/2003/2003474DC.htm

Liu, F.W. (2012). The politics of divide: Representation and the Torres Strait diaspora. GSTF International Journal of Law and Social Sciences, 1(1), 24-29.

Mayotte (2019). Encyclopcedia Britannica. Retrieved from https://www.britannica.com/place/Mayotte

McElroy, J., \& Mahoney, M. (2000). The propensity for political dependence in island microstates. Insula, 9(1), 32-35. https://doi.org/10.1080/14662043.2012.729727

McElroy, J., \& Sanborn, K. (2005). The propensity for dependence in small Caribbean and Pacific Islands. Bank of Valetta Review, 31(Spring), 1-16. https://www.um.edu.mt/library/oar//handle/123456789/40493

Monnerie, D. (2003). Résistance au colonialisme, culture, coutume et politique (Arama et région Hoot ma Whaap: Pratiques et représentations historiques et contemporaines. Journal de la Société des Océanistes, 117(2), 213-231. https://doi.org/10.4000/jso.1289

Mrgudovic, N. (2012). Evolving approaches to sovereignty in the French Pacific. Commonwealth and Comparative Politics, 50(4), 456-473. https://doi.org/10.1080/14662043.2012.729730

Muñoz, D. (2014). Kinship predicaments in Rapa Nui (Easter Island): Autochthony, foreign and substantial identities. Rapa Nui Journal, 28(2), 25-34. https://doi.org/10.1353/rnj.2019.0004

Palayret, G. (2004). Overseas France and minority and indigenous rights: Dream or reality? International Journal on Minority and Group Rights, 10, 221-252. https://doi.org/10.1163/1571811031310701

Pantz, P.C. (2018). La Nouvelle-Calédonie vote à 56,4 \% pour rester française. Le Monde, 5 November. $\quad$ Retrieved from https://www.lemonde.fr/politique/article/2018/11/04/nouvelle-caledonie-un-tauxde-participation-au-referendum-de-41-81-a-la-mi-journee $5378556 \quad 823448 . h t m l$

Pereyra-Uhrle, M. (2005). Easter Island land law. Yearbook of the New Zealand Association for Comparative Law, 11, 133-142.

Pöllath, M. (2018). Revisiting island decolonization: The pursuit of self-government in Pacific island polities under US hegemony. Island Studies Journal, 13(1), 235-250. https://doi.org/10.24043/isj.46

Prinsen, G., \& Blaise, S. (2017). An emerging 'islandian sovereignty' of non-self-governing islands. International Journal: Canada's Journal of Global Policy Analysis, 72(1), 56-78. https://doi.org/10.1177\%2F0020702017693260

Rezvani, D.A. (2014). Surpassing the sovereign state: The wealth, self-rule, and security advantages of partially independent territories. Oxford: Oxford University Press. https://doi.org/10.1093/acprof:oso/9780199688494.001.0001 
Sanders, W.G., \& Arthur, W.S. (2001). Autonomy rights in Torres Strait: From whom, for whom, for or over what? Discussion Paper No. 215, Centre for Aboriginal Economic Policy Research.

Silva Neriz, H. (2013). Chile. In C. Mikkelsen (Ed.). The Indigenous World (pp. 188-196). Copenhagen: International Work Group for Indigenous Affairs (IWGIA).

Stuart, K. (2008). A global listing of sub-national island jurisdictions. In G. Baldacchino \& K. Stuart (Eds.). Pulling strings: Policy insights for Prince Edward Island from other sub-national island jurisdictions (pp. 173-185). Charlottetown: Island Studies Press. https://doi.org/10.1080/00358530600929735

Teave, E., \& Cloud, L. (2014). Rapa Nui National Park, cultural world heritage: The struggle of the Rapa Nui people for their ancestral territory and heritage, for environmental protection, and for cultural integrity. In S. Disko \& H. Tugendhat (Eds.). World heritage sites and Indigenous peoples' rights (pp. 403-422). Copenhagen: International Work Group for Indigenous Affairs (IWGIA). https://doi.org/10.1163/9789004342194004

Torres Strait Island Regional Council (2016). Governance history. Retrieved from http://www.tsirc.qld.gov.au/changing-region/governance-history\#

Trépied, B. (2016). Urban Kanak parents on customary trial: An ethnography of the customary family court of Nouméa, New Caledonia. City \& Society, 28(1), 99-122.

Trompf, G. (1993). Islands and enclaves: Nationalisms and separatist pressures in island and littoral contexts. New Delhi: Sterling.

Uimonen, J. (2014). The personal status in French Law: With special focus on Overseas Territories. International Journal on Minority and Group Rights, 21, 451-468. https://doi.org/10.1163/15718115-02104001

United Nations (2007). United Nations declaration on the rights of Indigenous peoples. Retrieved from http://www.un.org/esa/socdev/unpfii/documents/DRIPS en.pdf

van der Grijp, P. (2005). Development Polynesian style: Contemporary Futunan social economy and its cultural features. The Journal of the Polynesian Society, 114(4), 311.

Young, F.W. (2019). Rapa Nui. The Contemporary Pacific, 31(1), 225-234.

Young, F.W. (2015). Rapa Nui. The Contemporary Pacific, 27(1), 281-293.

Young, F.W. (2013). Rapa Nui. The Contemporary Pacific, 25(1), 172-183.

Ziller, J. (2009). French overseas: New Caledonia and French Polynesia in the framework of asymmetrical federalism and shared sovereignty. In J.C. Oliveira \& P. Cardinal (Eds.). One country, two systems, three legal orders - perspectives of evolution (p. 443-460). Verlag, Berlin, Heidelberg: Springer. https://doi.org/10.1007/978-3-540-68572-2 26 
Cadey Korson, Sybille Poaouteta, E Gerard Prinsen 